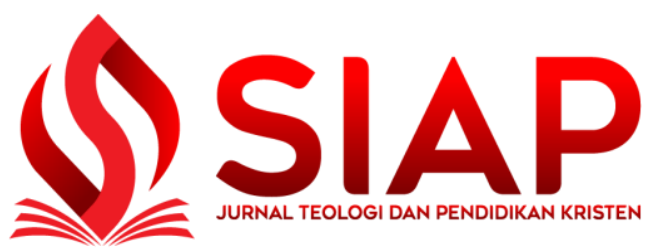

\title{
PENGARUH BIAS KOGNITIF TERHADAP PENERIMAAN INJIL SEBAGAI KEBENARAN YANG ABSOLUT
}

\begin{abstract}
Hery Susanto
Sekolah Tinggi Teologi Jemaat Kristus Indonesia h.susanto@sttjki.ac.id

\begin{tabular}{|l|l|l|}
\hline Diterima : 15 Desember 2021 & Direvisi : 19 Desember 2021 & Disetujui : 20 Desember 2021 \\
\hline
\end{tabular}

\section{ABSTRACT}

Cognitive bias is the formation of ideas because someone already has information about something, so in correlation with decision making it can result in thinking errors or difficulty adapting to change. Its connection with acceptance of the Bible as an absolute truth must be based on true knowledge and not based on cognitive biases that are also found in the Bible. So this article will describe various cognitive biases and examples in the Bible so that they can be taken into consideration when someone wants to make a decision to accept the Bible as an absolute truth.
\end{abstract}

Keywords: cognitive bias, truth, Bible, absolute

\section{ABSTRAK}

Bias kognitif adalah pembentukan gagasan karena seseorang telah memiliki informasi tentang sesuatu hal, sehingga dalam korelasinya dengan pengambilan keputusan dapat mengakibatkan kesalahan pemikiran atau sulit untuk beradaptasi dengan perubahan. Keterkaitannya dengan penerimaan terhadap Injil sebagai sebuah kebenaran absolut harus didasarkan pada pengetahuan yang benar dan bukan berdasar pada bias kognitif yang juga terdapat di dalam Alkitab. Jadi artikel ini akan menguraikan tentang berbagai bias kognitif dan contohnya di dalam Alkitab sehingga dapat menjadi bahan pertimbangan ketika seseorang hendak mengambil keputusan menerima Injil sebagai suatu kebenaran yang absolut.

Kata Kunci : bias kognitif, kebenaran, Injil, absolut 


\section{PENDAHULUAN}

Bias kognitif adalah pembentukan gagasan yang kuat terbentuk oleh informasi aatu pengetahuan yang dimiliki sebelumnya. Ide tentang bias kognitif ini dicetuskan oleh Amos Tversky dan Daniel Kahneman dalam artikel 1974 di Science. ${ }^{1}$ Pada musim gugur 1969, Amos Tversky dan Daniel Kahneman di departemen psikologi di Hebrew University of Jerusalem mengubah cara kita berpikir tentang pengambilan keputusan. Pasangan ini menciptakan bidang perilaku ekonomi dan merevolusi sebagian besar psikologi kognitif. Tversky meninggal pada tahun 1996, Kahneman pada tahun 2002, dianugerahi hadiah Nobel Memorial dalam Ilmu Ekonomi. Mereka berdua mendapatkan hadiah Nobel untuk pemikirannya yang mempengaruhi dunia pada saat itu.

Dalam perkembangannya bias kognitif ini dapat berpengaruh buruk dalam pengambilan keputusan karena seseorang menerima informasi dan mengikutinya dan menganggapnya sebagai kebenaran sekalipun ada banyak keterbatasan informasi yang dimilikinya. Lalu apa bedanya dengan fallacy (sesat berpikir) dan bias kognitif? Bias kognitif sering dikacaukan dengan fallacy atau kesalahan logika. Bias kognitif mengacu pada pola berpikir internal yang memengaruhi cara memproses informasi. Sedangkan sebuah fallacy- kesalahan logis mengacu pada kesalahan dalam penalaran yang melemahkan atau membatalkan argumen. Bias kognitif adalah kesalahan sistematis dalam cara berpikir subjektif seseorang, sedangkan kesalahan logis adalah tentang kesalahan dalam argumen logis².

Berkaitan dengan penginjilan, seseorang menerima kebenaran Injil bukan dikarenakan bias kognitif sekalipun itu sangat dimungkinkan untuk dapat terjadi. Seseorang menerima Kabar Baik sebagai kebenaran bukan dalam rangka untuk menunnjukkan dirinya sebagai yang paling benar dan tidak dapat diganggu gugat, tetapi justru memiliki sikap terbuka kepada perkembangan

\footnotetext{
${ }^{1}$ Kahneman, Daniel. (2011). Thinking Fast and Slow. Farrar, Straus and Giroux.

${ }^{2}$ Madyaningrum, Monica Eviandaru (2012). "Diskriminasi berdasar Identitas Sosial-Budaya dan Pendidikan HAM di Indonesia dalam Perspektif Psikologi Sosial." Jurnal Insan Media Psikologi 12.1
} 


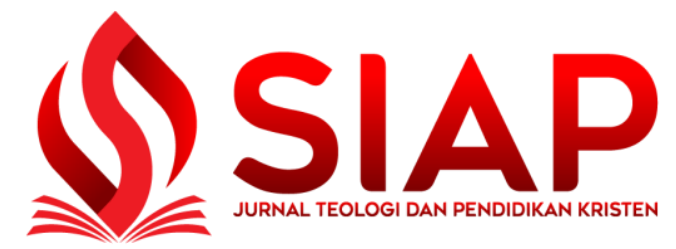

Vol. 10, No. 2 (Desember 2021)

Available Online at :

https://ejournal.sttjki.ac.id/index.php/siap/index

ISSN : 2302-5336X (Cetak) 2808-0459 (Online)

informasi yang memperkaya dan memperdalam kebenaran itu sendiri sebagai kebenaran yang absolut.

Jadi dalam artikel ini akan dijelaskan berbagai macam jenis bias kognitif dan contohnya dalam Alkitab sehingga dapat ditemukan korelasinya bahwa sejak mula manusia memiliki persoalan dengan sistem pengolahan pikirannya untuk mengambil keputusan. Secara khusus topik dalam artikel ini hanya akan mengaitkan bias kognitif dengan penginjilan dan responnya dalam pengambilan keputusan percaya kebenaran absolut Injil.

\section{METODOLOGI}

Metode yang digunakan dalam artikel ini adalah metode deskriptif kualitatif yaitu menggunakan kajian studi pustaka yang berkaitan dengan topik bias kognitif dan penginjilan. Di dalamnya akan diuraikan tentang bias kognitif dan bagaimana cara mengantisipasinya agar pengambilan keputusannya tidak didasarkan pada kesalahan berpikir tetapi benar-benar karena memahami kebenaran itu dengan jelas.

\section{DEFINISI}

Bias kognitif adalah gagasan kuat dan terbentuk sebelumnya tentang seseorang atau sesuatu, berdasarkan informasi yang dimiliki, dianggap memiliki, atau kekurangan informasi. Prakonsepsi ini adalah jalan pintas mental yang dihasilkan otak manusia untuk mempercepat pemrosesan informasi-untuk membantunya memahami apa yang dilihatnya dengan cepat.

Banyaknya jenis bias kognitif berfungsi sebagai kesalahan sistematis dalam cara berpikir subjektif seseorang, yang berasal dari persepsi, pengamatan, atau sudut pandang individu itu sendiri. Ada berbagai jenis bias yang dialami orang yang memengaruhi cara kita berpikir dan berperilaku, serta proses pengambilan keputusan kita.

\section{Jenis Bias Kognitif}

Ada berbagai bias kognitif umum yang ditunjukkan orang. Beberapa contoh bias kognitif adalah sebagai berikut:

\section{Bias Konfirmasi}




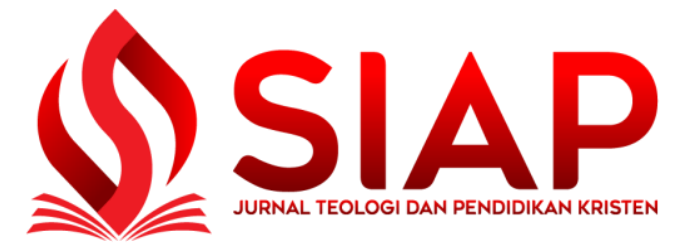

Vol. 10, No. 2 (Desember 2021)

Available Online at :

https://ejournal.sttjki.ac.id/index.php/siap/index

ISSN : 2302-5336X (Cetak) 2808-0459 (Online)

Bias konfirmasi ini mengacu pada kecenderungan untuk mencari informasi yang mendukung sesuatu yang sudah diyakini, dan merupakan bagian dari bias kognitif yang sangat merusak, seseorang mengingat suatu peristiwa dan melupakan kesalahan, yang merupakan cacat dalam penalaran manusia. Orang-orang akan memberi isyarat pada hal-hal yang penting bagi mereka, dan mengabaikan hal-hal yang tidak penting, sering kali mengarah ke "efek burung unta", di mana subyek mengubur kepala mereka di pasir untuk menghindari informasi yang mungkin menyangkal poin asli mereka.

Sebagai contoh di dalam peristiwa penyangkalan Petrus terhadap Yesus pada malam penangkapan Yesus (Markus 14:66-72). Petrus tahu bahwa jika dia mengaku mengenal Yesus maka dia akan ditangkap seperti Yesus yang diseret oleh para tentara dan dia mengingat peristiwa sebelumnya itu sebagai hal yang sangat traumatik. Akibatnya dia memilih mengambil keputusan untuk menyangkal bahwa dia salah satu muridNya, dan dia menyatakan tidak mengenal-Nya.

Bias konfirmasi ini juga dapat disebut "ostrich effect" yaitu menyembunyikan kepalanya hanya untuk menyelamatkan rasa malu dan harga dirinya sehingga dia memilih untuk mengingkari kebenaran sekalipun itu akan menyakiti dirinya sendiri.

\section{Bias Efek Dunning-Kruger}

Bias khusus ini disebut efek Dunning- Kruger mengacu pada bagaimana orang memandang suatu konsep atau peristiwa menjadi sederhana karena keterbatasan pengetahuan mereka tentang hal itu mungkin sederhana atau kurang - semakin sedikit tahu tentang sesuatu, semakin tidak rumit kelihatannya. Namun, bentuk bias ini membatasi keingintahuan-orang tidak merasa perlu untuk mengeksplorasi lebih jauh suatu konsep, karena bagi mereka tampaknya sederhana. Bias ini juga dapat membuat orang berpikir bahwa mereka lebih pintar dari yang sebenarnya, karena mereka telah mereduksi ide yang kompleks menjadi pemahaman yang sederhana. ${ }^{3}$

\footnotetext{
${ }^{3}$ Buana, D. R. (2020). Analisis perilaku masyarakat indonesia dalam menghadapi pandemi virus corona
} (Covid-19) dan kiat menjaga kesejahteraan jiwa. Salam: Jurnal Sosial dan Budaya Syar-i, 7(3), 217-226. 


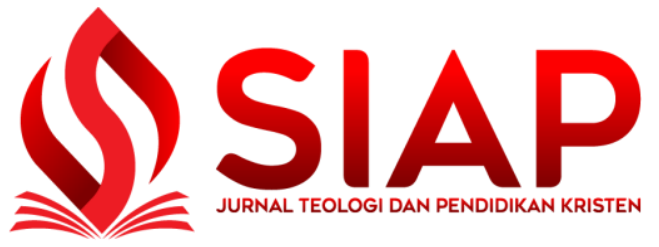

Vol. 10, No. 2 (Desember 2021)

Available Online at :

https://ejournal.sttjki.ac.id/index.php/siap/index

ISSN : 2302-5336X (Cetak) 2808-0459 (Online)

Injil bagi sebagian orang juga disederhanakan bahwa percaya kepada Yesus maka dia selamat. Sementara mereka tidak pernah memikirkan bagaimana arti percaya itu melibatkan seluruh 'belief system', tindakan yang mengekpresikan kepercayaan itu harus selaras dan lain sebagainya. Matius 19:16-26, mengisahkan tentang seorang pemuda kaya yang bertanya bagaimana memperoleh hidup yang kekal. Dia merasa bahwa semua perintah Taurat sudah dilakukannya, menjadi orang'baik', ternyata tidak cukup. Konsekwensi dari percaya Tuhan Yesus adalah rela melepaskan semua yang mengikat dirinya dan mengikut Yesus secara penuh. Memberi bukan dengan semua harta yang dimilikinya tetapi justru rela melepaskan itu semua untuk mendapat yang terbaik dari Tuhan.

Orang percaya masa kini juga menuntut Tuhan untuk mengikuti kemauannya karena dia sudah 'percaya' kepada Yesus. Sayangnya mereka tidak memahami bahwa arti 'percaya' itu bukan sekedar mengaku dengan mulut tapi dihidupi dengan seluruh pengetahuan, hati, dan nyawanya bahwa Yesus memang adalah juruselamat. Kecenderungan orang yang memegang konsep ini adalah kekecewaan karena tidak mendapatkan apa yang dia pikir sebagai kebenaran secara sederhana itu, hingga dia akan menyalahkan kebenaran itu sebagai kepalsuan karena yang dialami berbeda dengan fakta bahwa mengikut Yesus tidak semudah itu. Yesuspun melakukan tugas pengampunan dosa yang sebenarnya bisa disederhanakan tetapi tidak dilakukan karena konsekwensi dosa bukan hal yang sederhana tapi masalah serius yang harus ditangani dengan serius pula. Bisa saja Yesus mengampuni orang berdosa tanpa harus mati dan bangkit, difitnah dan dihina. Tetapi Yesus tidak akan mengkhianati apa yang ditugaskan Allah Bapa di surga. Yesus harus mati untuk mengalahkan kuasa maut sebagai upah dosa dan sesudah itu Yesus dimuliakan sebagai Raja. Kisah yang kompleks bukan? Dia tetap adil dan memegang kesepakatan yang terjadi dengan manusia tanpa ada keringanan atau negosiasi penyederhanaan.

Jika iman Kristen saja seperti itu, maka semestinya jangan berharap bahwa menjadi Kristen itu otomatis menerima keselamatan secara sederhana. Iman Kristen seharusnya justru 


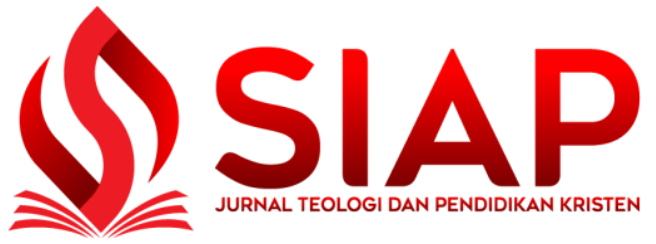

Vol. 10, No. 2 (Desember 2021)

Available Online at :

https://ejournal.sttjki.ac.id/index.php/siap/index

ISSN : 2302-5336X (Cetak) 2808-0459 (Online)

dapat menghargai pegorbanan Yesus sebagai tindakan kebenaran yang tidak mengingkari keadilan dan kedaulatan Tuhan atas manusia / dunia.

Bias dalam kelompok

Jenis bias ini mengacu pada bagaimana orang lebih cenderung mendukung atau mempercayai seseorang dalam kelompok sosial mereka sendiri daripada orang luar. Bias ini cenderung menghilangkan objektivitas dari segala jenis seleksi atau proses perekrutan, karena cenderung menyukai mereka yang kita kenal secara pribadi dan ingin membantu.

Di era sosial sekarang ini, peran komunitas atau kelompok sosial sangat dominan untuk menjadikan seseorang idola atau sebaliknya. Orang tidak peduli apakah yang dikatakan benar atau tidak karena yang lebih penting menjadi fans orang itu sehingga apapun yang dikatakan akan disetujui dan dianggap sebagai kebenaran. Sosial media sangat mendukung hal ini karena memang itu yang diinginkan bagi seseorang untuk memiliki banyak followers dan me-repost tayangan tokoh idola tersebut ${ }^{4}$.

Di dalam kisah Alkitab hal ini juga terjadi karena kehadiran Yesus sangat meresahkan para ahli Taurat dan orang Farisi yang selama ini memiliki pengikut banyak. Pengikut mereka adalah orang-orang yang dibayangi ketakutan akan hukuman jika melanggar hukum Taurat akan membahayakan hidupnya. Sementara Yesus memberikan pengetahuan dan kesadaran hidup di dalam kasih karunia Allah dengan cara yang berbeda. Matius 5:17-48 menjelaskan bahwa kedatangan Yesus ke dunia untuk menjalankan tugasnya bukan untuk meniadakan hukum Taurat tapi menggenapinya (ayat 17), bahkan Dia menyindir para ahli Taurat sebagai orang-orang yang taat menjalankan Taurat (ay.20). Yesus justru mengangkat esensi dari hukum Taurat itu adalah kasih yang diatas rata-rata yaitu mengasihi musuh (ay. 44). Siapakah musuh yang dimaksud? Adalah kelompok orang-orang yang tidak menyukai dan mengasihi umat Tuhan.

\footnotetext{
${ }^{4}$ Madyaningrum, M. E. (2012). Diskriminasi berdasar Identitas Sosial-Budaya dan Pendidikan HAM di
} Indonesia dalam Perspektif Psikologi Sosial. Jurnal Insan Media Psikologi, 12(1). 


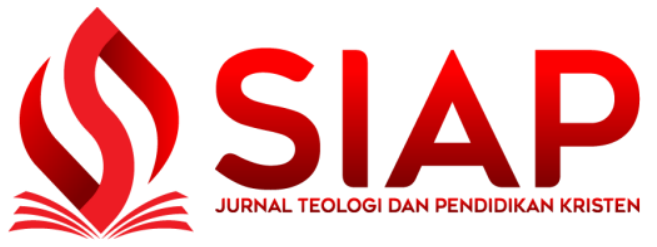

Vol. 10, No. 2 (Desember 2021)

Available Online at :

https://ejournal.sttjki.ac.id/index.php/siap/index

ISSN : 2302-5336X (Cetak) 2808-0459 (Online)

Pengajaran Yesus menjadi sangat kontroversial karena sama sekali tidak mengajarkan penghukuman kepada sesama tapi justru mengasihi siapapun yang Tuhan hadapkan kepada kita. Ini menjadikan kebenaran itu dipertentangkan dengan pengertian ahli Taurat yang bersifat menekankan ketaatan dan ketundukan pada hukum sebagai nilai tertinggi, tetapi melupakan esensi kasih yang harus menjiwai setiap perbuatan dan tindakan manusia. ${ }^{5}$

Bias melayani diri sendiri

Bias melayani diri sendiri adalah asumsi bahwa hal-hal baik terjadi pada kita ketika kita telah melakukan semua hal yang benar, tetapi hal-hal buruk terjadi pada kita karena keadaan di luar kendali kita atau hal-hal yang dimaksudkan orang lain. Bias ini menghasilkan kecenderungan untuk menyalahkan keadaan luar atas situasi yang buruk daripada mengambil tanggung jawab pribadi.

Bias ini sangat berbahaya karena dapat mengukur segala sesuatu dari segala yang dikerjakannya apakah sudah semua benar atau belum. Di satu sisi ada baiknya pemikiran ini untuk melakukan introspeksi diri tetapi bisa menjadi berbahaya karena ukuran kebenaran diukur dari dirinya sendiri. Sebagai contoh seseorang yang mengalami sakit dan masalah bertubi-tubi membuat kesimpulan seolah itu karena kesalahan dirinya sendiri. Padahal dia sudah melakukan banyak hal baik, berbuat amal, menolong sesama, tetapi tetap mengalami kesukaran. Subyektifitas ini sangat berbahaya untuk dapat dibagikan kepada orang lain karena ukurannya sangat subyektif dan relatif. ${ }^{6}$

Ketika seorang hamba Tuhan mengukur kesetiaannya dengan seberapa banyak dan besar pelayanannya, maka sebenarnya bias ini sudah menguasai kognitifnya. Tuhan tidak melihat seberapa besar pelayanan atau seberapa sibuk seseorang melayani Dia, tetapi lebih

${ }^{5}$ Sanda, H. Y. (2015). Yesus kristus tuhan dari semua orang menurut kisah para rasul 10: $34-36$ refleksi teologis dan respons iman kristen atas interpretasi para teolog pluralis dan inklusifis agama-agama (suatu studi eksegesis) (doctoral dissertation, sekolah tinggi teologi injili arastamar (setia) jakarta.

${ }^{6}$ Marisi, C. G., Sutanto, D., \& Lahagu, A. (2020). Teologi Pastoral dalam Menghadapi Tantangan Kepemimpinan Kristen di Era Post-Modern: Tinjauan Yesaya 40: 11. DIEGESIS: Jurnal Teologi Kharismatika, 3(2), 120-132. 


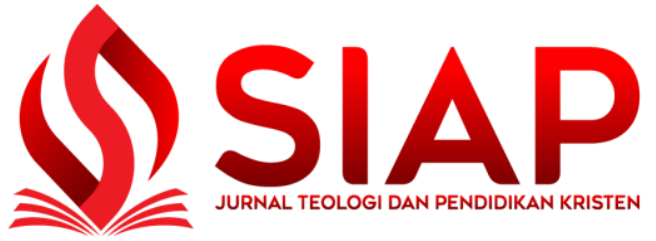

Vol. 10, No. 2 (Desember 2021)

Available Online at :

https://ejournal.sttjki.ac.id/index.php/siap/index

ISSN : 2302-5336X (Cetak) 2808-0459 (Online)

menuntut hati yang tulus murni dalam menjalankan misi Tuhan. Jika dibandingkan dengan pelayanan Paulus, maka semakin Nampak bahwa apa yang diperoleh Paulus dari pelayanannya justru penderitaan karena banyak orang memusuhi dia, dicaci maki dan dianggap remeh. Tetapi dengan sikapnya yang tunduk pada otoritas Tuhan Yesus maka segalanya menjadi berbeda. Ukuran keberhasilannya bukan lagi kebaikannya sendiri tetapi adalah karena dia menganggap hidupnya untuk Kristus dan sekalipun harus mati, itu adalah keuntungan (Filipi 1:21). Bagi Paulus hidupnya yang sekarang bukan lagi dirinya tetapi Kristus yang hidup di dalam dirinya oleh iman kepada Anak Allah yang mengasihi dirinya dan menyerahkan diriNya untuk Paulus (Galatia 2:20).

Paulus tidak terpancing untuk mengukur keberhasilannya dari seberapa baik pelayanannya, tetapi berserah kepada Tuhan sepenuhnya. Paulus tahu bahwa hidupnya sangat bergantung kepada Allah, bukan sebaliknya sehingga apa yang dilakukannya adalah bentuk ketundukannya pada Allah.

\section{Bias ketersediaan}

Bias ini disebut sebagai heuristik ketersediaan, mengacu pada kecenderungan untuk menggunakan informasi yang dapat diingat dengan cepat saat mengevaluasi topik atau idesekalipun informasi ini bukan representasi terbaik dari sebuah topik atau ide. Dengan menggunakan jalan pintas mental ini, informasi yang paling mudah diingat sebagai valid, dan mengabaikan solusi atau pendapat alternatif lain yang barangkali lebih bisa dipertanggungjawabkan.

Suatu hal yang traumatis dapat menjadikan informasi itu begitu kuat sehingga langsung diyakini sebagai kebenaran karena terasa sangat nyata dalam pengalaman kognitifnya. Sebagai contoh, ketika seseorang sedang berduka, ketika malam dia tertidur dan bertemu dengan ibunya yang sudah meninggal dan dalam mimpi itu ibunya membelai-belai rambutnya. Ketika dia bangun, dia menjadi tenang karena mimpi itu berkesan nyata dan seolah-olah itu pesan dari ibunya. Hal ini menunjukkan bahwa informasi yang disampaikan dianggap valid sekalipun itu terjadi di bawah sadar. 


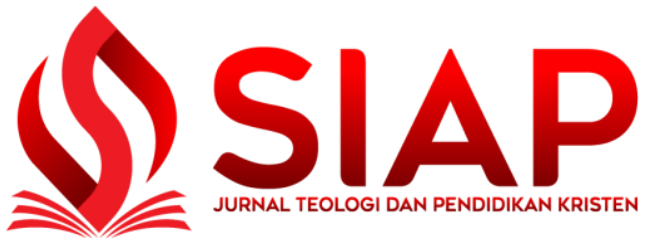

Vol. 10, No. 2 (Desember 2021)

Available Online at :

https://ejournal.sttjki.ac.id/index.php/siap/index

ISSN : 2302-5336X (Cetak) 2808-0459 (Online)

Di dalam Alkitab, Yesus menunjukkan berbagai kebenaran dalam pengajaran dan kuasa mujizat yang dilakukan-Nya sehingga memberikan kesan mendalam bagi para pendengar-Nya. Orang buta melihat (Markus 8:22-26), orang lumpuh berjalan (Matius 15:30), orang kerasukan dibebaskan (Markus 5:1-17), dan banyak hal lain yang menunjukkan informasi yang sangat otentik. Resiko lain yang dapat muncul adalah ketika peristiwa mengagumkan itu dilakukan oleh para dukun atau penyembah baal sehingga membuat merekapun mengalami bias dalam pengambilan keputusan karena sumbernya yang keliru. Misalnya adalah para dukun pada masa Firaun dan Musa (Keluaran 7:11). Mereka juga berusaha melakukan tindakan supranatural tetapi tidak mampu menandingi kuasa Tuhan melalui Musa.

Pada jaman sekarang, orang lebih mudah percaya pada demonstrasi mujizat baik dalam suasana ibadah maupun dalam model pengobatan alternatif. Situasi itu dapat melemahkan kebenaran yang dipercayai karena belum tentu apa yang terjadi pada seseorang juga terjadi untuk orang lain. Artinya pengalaman supranatural itu bersifat pribadi dan tidak bisa disamaratakan menjadi kebenaran universal. Bias yang terjadi adalah karena hal semacam ini kemudian didengungkan dan seolah menjadi demonstrasi kebenaran yang lebih valid daripada yang tidak mengalaminya ${ }^{7}$.

\section{Bias Kesalahan Atribusi Mendasar}

Bias ini mengacu pada kecenderungan untuk mengaitkan perilaku tertentu seseorang dengan stereotip yang ada dan tidak berdasar sambil menghubungkan perilaku kita sendiri yang serupa dengan faktor eksternal. Misalnya, ketika seseorang dalam tim Anda terlambat menghadiri rapat penting, Anda mungkin menganggap bahwa mereka malas atau kurang motivasi tanpa mempertimbangkan faktor internal dan eksternal seperti penyakit atau kecelakaan lalu lintas yang menyebabkan keterlambatan tersebut. Namun, ketika Anda terlambat karena ban kempes, Anda mengharapkan orang lain untuk menghubungkan kesalahan dengan faktor eksternal (ban kempes) daripada perilaku pribadi Anda.

\footnotetext{
${ }^{7}$ Supriadi, M. N. (2020). Tinjauan Teologis Terhadap Postmodernisme Dan Implikasinya Bagi Iman Kristen.
} Manna Rafflesia, 6(2), 112-134. 


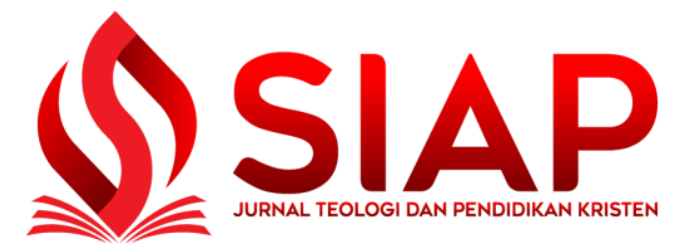

Vol. 10, No. 2 (Desember 2021)

Available Online at :

https://ejournal.sttjki.ac.id/index.php/siap/index

ISSN : 2302-5336X (Cetak) 2808-0459 (Online)

Kecenderungan untuk melempar kesalahan kepada orang lain dan memberikan cap kepada orang lain sebagai orang yang lemah dan salah. Sementara ketika diri kita yang diserang dengan kesalahan, dengan cepat reaksi utamanya adalah berkelit dan menyalahkan hal-hal lain di sekitar kita.

Kisah Alkitab juga menyebutkan orang-orang yang lebih suka menghakimi orang lain padahal dirinya sendiri memiliki kesalahan dalam hidupnya. Matius 7:1-5 menerangkan bahwa ada orang yang lebih suka melihat selumbar di mata saudaranya sedangkan balok di matanya sendiri tidak diketahui. ${ }^{8}$

\section{Bias Melihat ke Belakang}

Bias melihat ke belakang, dikenal sebagai efek mengetahui segalanya, adalah ketika orang menganggap peristiwa lebih dapat diprediksi setelah terjadi. Dengan bias ini, orang melebih-lebihkan kemampuan mereka untuk memprediksi hasil sebelumnya, meskipun informasi yang mereka miliki pada saat itu tidak akan membawa mereka ke hasil yang benar. Jenis bias ini sering terjadi dalam olahraga dan urusan dunia. Bias melihat ke belakang dapat menyebabkan terlalu percaya diri pada kemampuan seseorang untuk memprediksi hasil di masa depan. Kadangkala bias ini bisa dilihat secara positif sebagai orang yang optimis karena melihat kemampuan mereka sehingga dapat meprediksikan apa yang akan terjadi untuk orang tersebut. Namun dari sisi yang lain dapat berbahaya karena setiap pengalaman rohani seseorang tidak dapat dirumuskan secara matematis. Maksudnya jika keluarganya diberkati dengan kepandaian atau rejeki, bisa jadi dia mengukur Tuhan dengan cara yang keliru bahwa Dia selalu memberkati dan tidak menghukum orang melalui kesulitan dalam kehidupan. Ketika mengalami kesulitan, maka rasa bersalah dan dosa menghantuinya. Akibatnya secara spiritual, dia menjadi sangat sensitif dan mudah jatuh bangun dengan imannya?

\footnotetext{
${ }^{8}$ Roskowski, M. (2013). Absurdity and the Leap of Faith.

${ }^{9}$ Garelick, H. M. (1965). Subjectivity. In The Anti-Christianity of Kierkegaard (pp. 19-27). Springer,
} Dordrecht. 


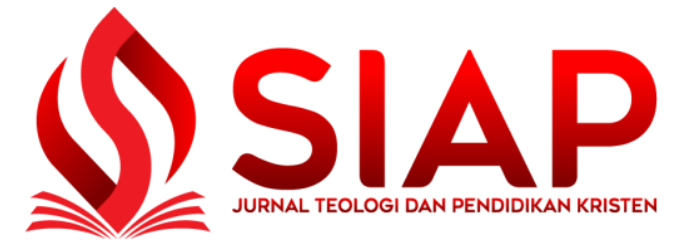

Vol. 10, No. 2 (Desember 2021)

Available Online at :

https://ejournal.sttjki.ac.id/index.php/siap/index

ISSN : 2302-5336X (Cetak) 2808-0459 (Online)

Salah satu contoh di Alkitab yang berdampak positif adalah Zakheus (Lukas 19:1-10), sebagai seorang pemungut cukai yang korup, tetapi rindu melihat Yesus. Hanya untuk melihat saja itu sudah cukup. Tetapi dia tidak pernah menyangka bahwa Yesus mau menumpang di rumahnya. Dialog berikutnya membuat hati Zakheus bersukacita dan mengambil keputusan melampaui logikanya bahwa dia mau mengembalikan kepada orang pernah diperasnya empat kali lipat dan setengahnya diberikan kepada orang miskin (ay. 9).

Tindakan Zakheus tentu saja mengejutkan orang-orang di sekitarnya pada saat itu, namun menjadi sukacita bagi Zakheus karena dia menemukan bahwa apa yang dikejarnya selama ini adalah suatu kesalahan. Perubahan yang terjadi merupakan bukti bahwa dia sudah mengubah mindsetnya tentang Tuhan karena pengenalannya secara pribadi membuktikan bahwa Yesus tidak seperti yang dia bayangkan, yang menjaga jarak dengan orang berdosa seperti dirinya, justru sebaliknya mau datang ke rumah orang berdosa seperti dirinya.

\section{Bias Penahan}

Bias penahan, juga dikenal sebagai fokalisme atau efek penahan, berkaitan dengan mereka yang terlalu bergantung pada informasi pertama yang mereka terima-fakta "penahan" - dan mendasarkan semua penilaian atau opini selanjutnya pada fakta ini.

Ketika informasi pertama yang diterima itu meyakinkan, biasanya seseorang tidak akan mudah beralih ke informasi yang lain, walaupun sebenarnya informasi tersebut belum tentu benar. Artinya pada bias kognitif yang ini, orang cenderung untuk tidak mau mencari informasi pendukung lain karena dianggap sudah cukup.

Bias ini menjadikan orang berpikir picik, karena tidak terbuka pada sumber pengetahuan baru yang berbeda dari apa yang sudah diyakininya. Keberadaan bias ini mempengaruhi orang untuk sulit bergeming dengan perkembangan informasi yang sekarang ada. Sebagai contoh konkrit, tentang keberadaan vaksin covid yang disosialisasikan pemerintah. Sebagain orang tidak yakin bahwa mereka perlu divaksin, karena menurut mereka 


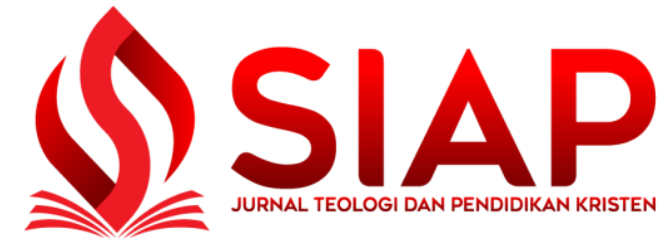

Vol. 10, No. 2 (Desember 2021)

Available Online at :

https://ejournal.sttjki.ac.id/index.php/siap/index

ISSN : 2302-5336X (Cetak) 2808-0459 (Online)

itu adalah anti-kris ${ }^{10}$. Informasi salah yang diterima tidak berdasar, tetapi karena yang menyampaikan itu seorang hamba Tuhan, maka mereka meyakininya sebagai kebenaran. Mereka tidak terbuka untuk melihat realita di sekitarnya yang sudah berbeda dengan jaman dulu sebelum ada virus covid.

Banyak pula contoh di Alkitab yang menceritakan kesulitan meyakinkan seseorang karena sikap antipasti pada informasi baru atau berita baru yang sebenarnya dapat mengubah kehidupan mereka lebih baik lagi. Abraham dan Sara yang menanggapi secara mentah tentang janji Allah tentang anak yang akan mereka miliki menjadikan Sara mentertawakan perkataan malaikat (Kej. 17:17), akan berahikah aku sedangkan aku sudah layu dan tuanku sudah tua (Kej. 18:12). Keraguan itu selalu menjadi bayang-bayang mengganggu karena imannya menuntut percaya sepenuhnya kepada perkataan Tuhan. Musa juga meragukan apakah dirinya bisa memimpin bangsanya keluar dari Mesir karena dia merasa bahwa dirinya tidak cakap bicara (Kel. 3:10-12).

\section{Bias Optimisme}

Bias ini mengacu pada bagaimana kita sebagai manusia lebih cenderung memperkirakan hasil positif jika kita dalam suasana hati yang baik. Optimisme itu positif tetapi seringkali berbuah pada kekecewaan karena hasilnya tidak sesuai dengan harapan. Optimisme juga membuat sebuah perencanaan kurang memikirkan factor resiko dan tantangan. Optimisme berlebihan mengabaikan kelemahan dan keterbatasan dapat membuat seseorang justru melemah karena hasilnya tidak sesuai harapan ${ }^{11}$.

Sebagai orang percaya, tidak boleh terlalu optimis bahwa asal percaya Yesus, pasti masuk sorga. Sebuah kesalahan optimism karena untuk ikut Tuhan Yesus dibutuhkan lebih daripada sekedar percaya saja tetapi mewujudkan iman itu dalam tindakan dan semua

${ }^{10}$ Buana, D. R. (2020). Analisis perilaku masyarakat indonesia dalam menghadapi pandemi virus corona (Covid-19) dan kiat menjaga kesejahteraan jiwa. Salam: Jurnal Sosial dan Budaya Syar-i, 7(3), 217-226.

${ }^{11}$ Rahmania, F. A., Azmi, D. N., \& Dwicahyaputri, H. (2020). Bias Optimisme dan Perilaku Preventif Masyarakat pada Era New Normal. Psisula: Prosiding Berkala Psikologi, 2, 197-209. 


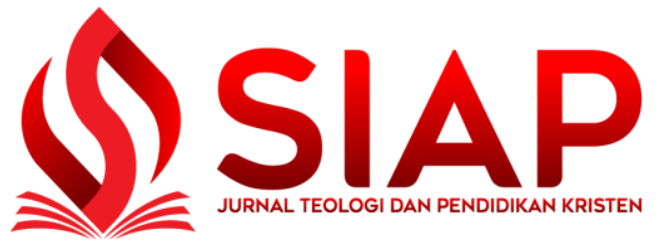

pengharapan tentang keselamatan itu adalah bentuk iman yang harus dipertanggungjawabkan dalam tindakan, perkataan dan sikap hati.

Yesus pernah menyampaikan optimism yang keliru dari seorang kaya yang sudah membuat rencana masa depan dengan sangat sempurna tetapi malah akhirnya dia mati dalam kesia-siaan sebelum semuanya tercapai (Lukas 12:13-21). Dalam akhir hidupnya, kepada siapakah semua hartanya diwariskan, siapa yang menikmati, semua sia-sia. Optimisme yang tidak memikirkan efek samping dari tindakannya menunjukkan ketidakbijakan seorang kaya itu.

\section{Bias Pesimisme}

Bias ini mengacu pada bagaimana kita sebagai manusia lebih cenderung memperkirakan hasil negatif jika kita sedang dalam suasana hati yang buruk. Mengapa hati yang buruk bisa mempengaruhi pikiran pesimis? Rupanya ada keterkaitan antara suasana hati dengan mentalitas seseorang. Alkitabpun mengatakan hati yang gembira adalah obat yang manjur (Amsal 17:22). Jadi semakin trampil mengendalikan hati makwa hasilnya pikirannyapun akan sehat dan tidak selalu negatif.

Ketika Yesus bertemu dengan seorang perempuan yang berbuat zinah dan hendak dirajam dengan batu, dia begitu ketakutan hingga tidak berani menatap Yesus (Yohanes 8:111). Pikirannya dibayangi ketakutan dan pesimisme. Dia begitu yakin bahwa dirinya memang layak dihukum dan tidak layak mendapatkan pengampunan. Ternyata pesimisme perempuan ini keliru, Yesus justru membalikkan keadaan tanpa menghakimi (ayat 9). Satu persatu orangorang yang tadinya berniat jahat untuk merajam perempuan itu pergi satu persatu karena merasa bahwa yang Yesus katakan itu benar. Jadi bias pesimisme seringkali berdampak kepada keruhnya masalah dan bukan pada pengenalan akan kebenaran. Yang dicari bukan benar salah tapi perasaan secure dalam pesimisme mereka ${ }^{12}$.

${ }^{12}$ Menon, G., Kyung, E. J., \& Agrawal, N. (2009). Biases in social comparisons: Optimism or pessimism?. Organizational Behavior and Human Decision Processes, 108(1), 39-52. 


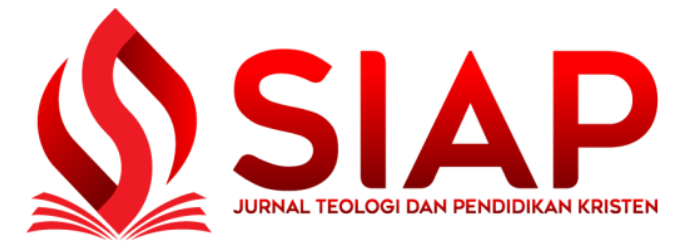

Vol. 10, No. 2 (Desember 2021)

Available Online at :

https://ejournal.sttjki.ac.id/index.php/siap/index

ISSN : 2302-5336X (Cetak) 2808-0459 (Online)

Kebenaran tidak bisa didekati dengan pesimisme karena akan terdistorsi dalam persepsi subyektif yang tidak dapat dipertanggungjawabkan. Yesus berkali-kali mengatakan dan membuktikan bahwa diri-Nya berasal dari Allah Bapa di surga, bukan dari dunia. Tentu saja skeptisisme mereka akan cenderung menyangkal kebenaran itu, tetapi pada akhirnya mereka melihat bahwa Yesus sungguh-sungguh dengan perkataan-Nya. Dia mati di kayu salib tanpa perlawanan dan melakukan-Nya dengan sepenuh hati demi melaksanakan amanat Bapa di surga. Pesimisme sangat berbahaya untuk ditanamkan dalam pikiran orang lain karena dapat menjadikan seseorang apriori terhadap hal-hal baru yang tidak sesuai dengan logikanya.

\section{Bias Efek Halo}

Bias ini mengacu pada kecenderungan untuk membiarkan kesan kita tentang seseorang, perusahaan, atau suatu hal dalam satu domain memengaruhi kesan kita secara keseluruhan tentang orang atau entitas tersebut. Misalnya, konsumen yang menikmati kinerja alat elektronik yang mereka beli dari merek tertentu lebih mungkin untuk membeli produk lain dari merek tersebut karena pengalaman positif mereka dengan alat elektronik merek tertentu. Artinya bias ini menyebabkan pandangan kita akan suatu hal digeneralisasi kepada hal lain yang belum tentu sama benarnya. Misalnya jika seseorang memiliki HP Samsung, dan dia puas dengan HP itu, maka dia akan cenderung membeli televisi, kulkas dengan merek yang sama. Atau misalnya seseorang membeli gula di sebuah toko dengan harga selisih lebih murah dari toko lain, maka dia akan cenderung membeli barang-barang lain di toko itu pula walaupun belum tentu bahwa semua barang di situ harganya lebih murah ${ }^{13}$.

Bias Halo ini juga berbahaya dalam hal yang bersifat rohani misalnya jika seorang pendeta berkotbah dan pada suatu waktu kotbahnya begitu menyentuh hati umatnya se hingga mereka merasa bahwa pendeta itu memiliki urapan dari Tuhan dan kotbahnya pasti dari Tuhan. Lama kelamaan mereka tidak lagi meneliti atau merenungkan firman itu baik-baik hanya karena yang menyampaikannya adalah seorang pendeta yang pernah menyentuh hati

${ }^{13}$ Cherry, K. (2016). What is the halo effect. Psychology. about. com. 


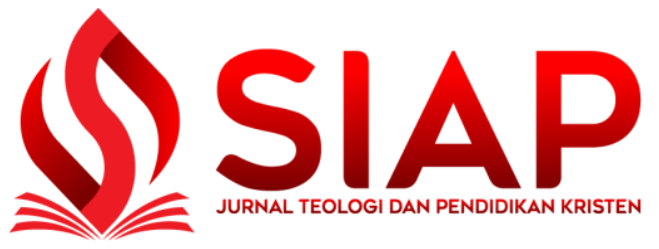

Vol. 10, No. 2 (Desember 2021)

Available Online at :

https://ejournal.sttjki.ac.id/index.php/siap/index

ISSN : 2302-5336X (Cetak) 2808-0459 (Online)

mereka. Dengan demikian pendangkalan teologis dapat terjadi karena lebih mengkultuskan penyampai Firman lebih dari kebenaran Firman itu sendiri.

Kesalahan dalam bias ini adalah selalu mengambil sampel untuk menjadikannya kebenaran umum. Contoh dalam Alkitab misalnya, jika engkau ditampar pipi kirimu berikanlah pipimu yang lain (Lukas 6:29), demikian pulalah tiap-tiap orang di antara kamu, yang tidak melepaskan dirinya dari segala miliknya, tidak dapat menjadi murid-Ku (Lukas 14:33). Ucapanucapan Yesus terkesan tajam dan berlebihan tetapi sesungguhnya kebenarannya ada pada kerendahan hati dan sikap yang tunduk kepada Tuhan. Jika hal itu dituruti dengan pengertian yang benar, maka tidak akan segegabah itu menerima kalimat perkataan Yesus. Memberikan pipi kepada orang yang menampar pipi bisa terkesan absurd, tetapi justru menunjukkan karakter yang bukan defensive tetapi receptive. Bukan pembelaan diri tetapi menerima dengan penuh kesadaran dan tidak membalas. Kebenarannya perlu ditelaah dengan bijak agar tidak sekedar menjadi manusia yang lemah karena tidak pernah melawan.

Contoh yang kedua tentang meninggalkan semuanya untuk menjadi murid Yesus, bukan berarti kita tidak boleh memiliki apa-apa, tetapi sikap hati yang mengutamakan Yesus di atas segala milik dan harta yang dipunyainya. Jika ditafsirkan secara literal maka akibatnya orang menjadi terlalu apatis terhadap dunia dan akibatnya menjadi orang yang 'aneh'.

\section{Bias Status Quo}

Bias status quo mengacu pada preferensi untuk menjaga hal-hal dalam keadaan mereka saat ini, sementara menganggap semua jenis perubahan sebagai kerugian. Bias ini mengakibatkan seseorang sulit untuk menerima perubahan. Seseorang yang memegang prinsip status quo termasuk orang yang teguh pendiriannya sehingga tidak mau diubah-ubah oleh siapapun ${ }^{14}$. Dalam ilmu filsafat disebut juga dengan fondasionalisme, di mana semua pemikirannya sudah berakar dan sulit tercabut. Semua keyakinan, iman, prinsip hidup dipegang erat dan sulit untuk diubah. Ahli taurat dan kaum Farisi adalah contoh sempurna

${ }^{14}$ Eidelman, S., \& Crandall, C. S. (2012). Bias in favor of the status quo. Social and Personality Psychology Compass, 6(3), 270-281. 


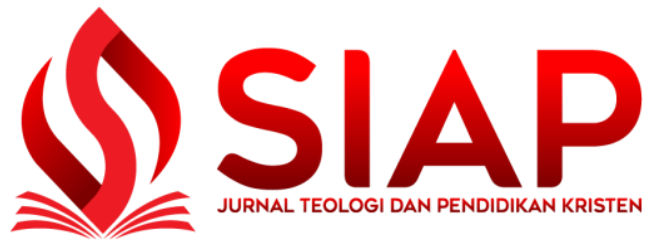

untuk orang-orang yang memilih memegang status quo. Mereka tidak mau berubah untuk menerima penjelasan yang sesungguhnya lebih komprehensif tentang hukum Taurat. Kegagalan menemukan kebenaran disebabkan terlalu meyakini apa yang selama ini sudah dipercaya dan diyakininya sehingga tidak mau meng-update pemikirannya dengan perkembangan informasi yang lebih komprehensif.

\section{Tindakan Pencegahan}

Bias kognitif ada pada segala kalangan manusia tanpa pandang bulu. Nampaknya hal itu bisa menghancurkan sistem kepercayaan manusia di berbagai bidang. Oleh sebab itu perlu tindakan preventif agar bahaya ini dapat dicegah.

\section{Sikap Terbuka pada Pemikiran Kritis}

Bias Kognitif terjadi karena cara berpikir yang keliru dalam membuat suatu keputusan. Oleh sebab itu waspada bahwa keadaan itu memang sudah ada sejak semula. Semakin kritis cara seseorang berpikir, maka akan terbuka pada berbagai faktor yang dapat mengubah cara pandang seseorang. Pemikiran kritis menolong seseorang untuk dapat mempertimbangkan berbagai hal sebelum mengambil keputusan yang diperlukan untuk membuat suatu kesimpulan dan menanggapi secara tepat.

\section{Sikap De-bias}

Jika kita menyadari bahwa setiap orang dapat membuat keputusan yang salah karena bias kognitif, maka pemikiran itu harus dicounter balik dengan sisi yang lain agar menemukan hal lain yang diperlukan agar keputusan yang dibuat tidak bias atau menyesatkan orang. Setiap informasi baru yang bertentangan dengan pengetahuan yang lama tidak langsung ditolak tetapi dipertimbangkan baik-baik.

\section{Membuat Batasan Pemikiran}

Dalam konteks bias pengamat, maka dilakukan studi pembatasan jumlah informasi yang diketahui. Tujuannya adalah untuk membatasi informasi yang dapat mempengaruhi perubahan pemikiran terhadap suatu pemahaman tertentu. Jadi pembatasan ini bukan berarti 


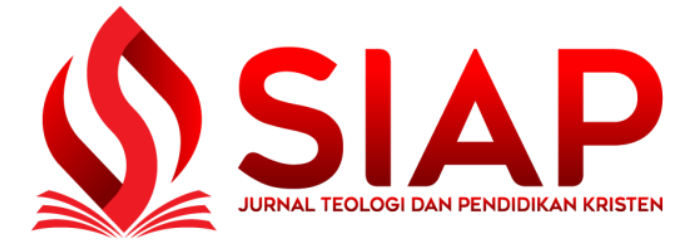

Vol. 10, No. 2 (Desember 2021)

Available Online at :

https:// ejournal.sttjki.ac.id/index.php/siap/index

ISSN : 2302-5336X (Cetak) 2808-0459 (Online)

tidak boleh mencari informasi lain, tetapi membatasi hingga tersedia kecukupan informasi dalam mengambil sebuah keputusan.

Korelasi Bias Cognitif Dengan Penginjilan

Bias kognitif dapat terjadi pada seseorang yang melakukan tugas penginjilan karena kurangnya penguasaan iman yang disampaikannya. Pengetahuan terhadap Injil dilandasi dengan iman kepercayaan yang kuat akan dapat menjadi indicator bahwa seseorang tidak sedang mengalami bias kognitif. Orang yang mendengarkan Injil diberitakan tidak merasa terpaksa untuk dapat mengambil keputusan dalam menentukan pilihan sikap untuk mempercayai atau menolak. Kebebasan ini adalah bagian dari penginjilan yang mengajak seseorang untuk menemukan kebenaran itu bukan karena terpaksa atau dirayu oleh sang pemberita Injil.

Kebenaran di dalam Alkitab itu diyakini sebagai kebenaran yang absolut, yang tidak memihak kepada salah satu agama saja. Sifatnya selalu merangkul dan terbuka bagi siapapun yang percaya dan menerimanya. Persoalan atau gesekan yang sering terjadi di Indonesia adalah ketika ada sentiment-sentimen agamawi yang menyebabkan orang merasa 'dikristenkan'15. Dalam perspektif umum dapat dipahami bahwa seseorang tidak mau mengubah keyakinan yang dipegangnya karena hal tersebut berisiko akan menyulitkan hidupnya, mengubah komunitasnya dan banyak factor lain untuk menjadi alasan menolak. Tetapi jika kebenaran itu bersifat absolut, maka itu yang harus disikapi dengan netral dan pemikiran kritis tanpa harus merasa 'tidak enak' dengan yang lain.

\section{KESIMPULAN}

Berbagai faktor dapat menyebabkan terjadinya bias dalam kognitif atau pemikiran seseorang, sehingga untuk menerima Injil sebagai kebenaran yang absolut membutuhkan kesadaran dan pemahaman yang lengkap tentang Injil. Hal itu tidak boleh didasari oleh ide-ide yang tidak mendasar seperti lingkungan, orang tua, doktrin gereja, ataupun pendapat

${ }^{15}$ Susanto, Hery (2021) Tinjauan Teologis Tentang Penginjilan Dalam Konteks Indonesia. Sagacity: Journal of Theology and Christian Education, 1 (2). pp. 56-64 
mayoritas. Mereka harus menemukan kebenaran itu dan menerapkannya dalam kehidupannya sehingga apa yang diyakininya itu dapat terekpresikan dengan baik dan benar.

Kebenaran Injil bukan sesuatu yang harus dipaksakan, tetapi ditemukan sendiri dengan informasi yang benar. Seklaipun dalam penyampaiannya dapat saja terjadi bahwa pihak penyampai memberikan informasi yang salah, tetapi Roh Kudus akan menolong manusia untuk dapat menemukan kebenaran itu sendiri sebagai sebuah kebenaran final yang absolut. 


\section{BIBLIOGRAFI}

Buana, D. R. (2020). Analisis Perilaku Masyarakat Indonesia dalam Menghadapi PAndemi Virus Corona (Covid-19) dan Kiat Menjaga Kesejahteraan Jiwa. Salam: Jurnal Sosial Dan Budaya Syar-I, 7(3), 217-226.

Cherry, K. (2016). What is the Halo Effect. In Psychology.about.com.

Eidelman, S.,\& CRandall, C. S. (2012). Bias in Favor of the Status Quo. Social and Personality Psychology Compass, 6(3), 270-281.

Garelick, H. M. (1965). Subjectivity. In The Anti-Christianity of Kierkegaard. Springer, Dordrecht Kahneman, D. (2011). Thinking Fast and Slow. Farrar, Straus and Giroux.

Madyanirngrum, M. E. (2012). Diskriminasi berdasar Identitas Sosial Budaya dan Pendidikan HAM di Indonesia dalam Perspektif Psikologi Sosial. Insan Media Psikologi, 12.1.

Marisi, C. G., Sutanto, D., \& Lahagu, A. (2020). Teologi Pastoral dalam Menghadapi Tantangan Kepemimpinan Kristen di Era Post-Modern: Tinjauan Yesaya 40: 11. DIEGESIS: Jurnal Teologi Kharismatika, 3(2), 120-132.

Menon, G., Kyung, E. J., \& Agrawal, N. (2009). Biases in social comparisons: Optimism or pessimism?. Organizational Behavior and Human Decision Processes, 108(1), 39-52.

Rahmania, F. A., Azmi, D. N., \& Dwicahyaputri, H. (2020). Bias Optimisme dan Perilaku Preventif Masyarakat pada Era New Normal. . Psisula: Prosiding Berkala Psikologi, 197-209.

Roskowski, M. (2013). Absurdity and The Leap of Faith.

Sanda, H. . (2015). YESUS KRISTUS TUHAN DARI SEMUA ORANG MENURUT KISAH PARA RASUL 10: 34-36 REFLEKSI TEOLOGIS DAN RESPONS IMAN KRISTEN ATAS INTERPRETASI PARA TEOLOG PLURALIS DAN INKLUSIFIS AGAMA-AGAMA (SUATU STUDI EKSEGESIS). Doctoral Dissertation, Sekolah Tinggi Teologi Injili Arastamar (SETIA) Jakarta.

Supriadi, M. N. (2020). Tinjauan Teologis Terhadap Postmodernisme Dan Implikasinya Bagi Iman Kristen. Manna Rafflesia, 6 (2), 112-134 


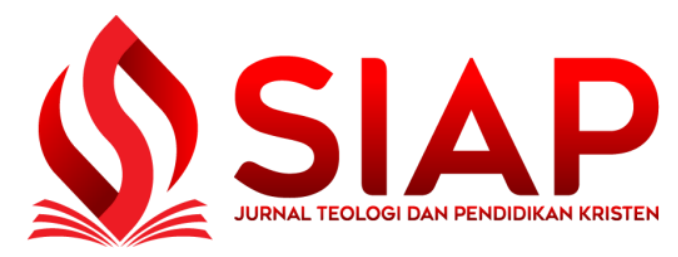

Vol. 10, No. 2 (Desember 2021)

Available Online at :

https://ejournal.sttjki.ac.id/index.php/siap/index

ISSN : 2302-5336X (Cetak) 2808-0459 (Online)

Susanto, H. (2021). Tinjauan Teologis Tentang Penginjilan Dalam Konteks Indonesia. Sagacity: Journal of Theology and Christian Education, 1 (2), 56-64.

https://repository.divinity.edu.au/4331/ 